\title{
All in one Thermoascus aurantiacus and its Industrial Applications
}

\section{Marwa O Elnahas, Waill A Elkhateeb*, Ghoson M Daba}

Chemistry of Natural and Microbial Products Department, Pharmaceutical Industries Division, National Research Centre, Dokki, Giza, 12622, Egypt.

\section{ARTICLE INFO:}

Received: 18 Nov 2020

Accepted: 20 Dec 2020

Published: 30 Dec 2020

\section{Corresponding author * Dr Waill A Elkhateeb, Chemistry of Natural and Microbial Products Department, Pharmaceutical Industries Division, National Research Centre, Dokki, Giza, 12622, Egypt. \\ E Mail: waillahmed@yahoo.com}

\begin{abstract}
:
Background: Fungi are well known biotechnological tools that have various applications in the fields of industry. Thanks to their ability to produce set of prestigious enzymes that is eco-friendly and can replace harmful chemicals used in those industries. Thermoascus is an ascomycetous fungus that belongs to family Trichocomaceae, which is famous for its promising mycotechnological applications due to its capability to produce potent heat stable enzymes such as cellulases, xylanases, and $\beta$-glucosidases.

Object: The aim of this review is to highlight the description. ecology, and important industrial applications of the genus Thermoascus in general, and the species Thermoascus aurantiacus in particular focusing on its heat-resistant hydrolase enzymes that have different potential biotechnological applications.

Conclusion: Thermoascus originated metabolites are of potential biological activities especially as antioxidant agents. Furthermore, enzymes produced by Thermoascus are involved as promising tool in many important mycotechnological applications such as food, textile, paper, pulp, animal feed, conversion of biomass into biofuels, as well as other chemical industries. Understanding the importance of these fungus thermostable enzymes may contribute in encouraging for further studies in order to employ them in new biotechnological fields. Enhancing the production of industrial thermostable enzymes from Thermoascus aurantiacus via the application of different statistical approaches and newly developed molecular biology methods is of critical importance. Furthermore, more effort should be directed towards introducing Thermoascus aurantiacus into new hosts for further studying the deconstruction of plant cell wall.
\end{abstract}

Keywords: Thermoascus aurantiacus, Thermostable enzymes, Industrial application, Biofuel.

\section{INTRODUCTION}

Thermophilic fungi have gained an importance as promising sources of thermostable enzymes that can improve the biochemical conversion of various natural resources to biofuels [1]. Numerous saprophytic fungi that can tolerate high temperatures (thermophiles) have been detected in various environments, like composts where organic matter are decomposed at high temperatures [2]. Continual consumption of non-renewable resources of energygaina lot of attention by many researchers and this encourages many scientists to utilize other renewable resources of energy, including secondary agriculture resources. One of these agriculture resources is lignocellulosic biomass that can be converted to many beneficial products [3].

Lignocellulose is one of the most abundant raw material that is composed mainly of cellulose, hemicellulose, and lignin [4]. On the other hand, glycoside hydrolases including cellulases and xylanases result in the release of monosaccharide units from both cellulose and hemicelluloses. These monosaccharides could be easily converted to many other valuable products [5]. As an example, the cellulases can break the cellulose into hexose sugars that in turn may be converted into ethanol. Also, xylanases can act on the xylan, that is abundant in wood biomass and break it into pentose sugars.

Most of the cellulases and xylanases are produced from mesophilic microorganisms which mean that they favour mesophilic ranges (from 40 to $50^{\circ} \mathrm{C}$ ) to act optimally. Nevertheless, thermostable enzymes exibit many advantages for optimum utilization of lignocellulose. Since these enzymes are compatible with the pretreatment procedures that require high temperatures [6], applying these thermostable enzymes will allow the pretreatment process to be more flexible [7]. Moreover, the saccharifications process of pretreated biomass at higher temperatures leads to the acceleration of the conversion process, resulting in shorter incubation periods as well as lowering the enzyme loadings. 
International Journal of Pharma Research and Health Sciences, 2020; 8 (6): 3237-3241

Another advantage for applying the thermostable enzymes is reducing the downstream contamination by competing other microorganisms for the fermentable sugars. For these reasons, thermophilic fungi may supply new enzymes that are useful for the industrial biochemical conversion of various biomasses into simple sugars and which could be fermented into biofuels [7-13].

Thermoascus aurantiacus is theromophilic fungus that is viewed as a promising source of industrially important enzymes for biomass deconstruction under thermophilic conditions. T. aurantiacus has been examined extensively for its ability to secrete large amounts of thermostable enzymes for the depolymerization of cellulose and hemicellulose from plant biomass. [14-19].

\section{Thermoascus aurantiacus description and ecology}

Thermoascus aurantiacus was described by a German mycologist "Hugo Miehe", it was isolated from self-heating hay [3, 4]. Miehe could not assign $T$. aurantiacus to any of the already known fungal genera, thus he created a genus named Thermoascus which returns to the Greek words "thermos"which means hot; and"askos" that means tube. Additionally, due to the golden/orange color of its fruiting bodies, he chose "aurantiacus" (lat., orange-colored) for the species name. Miehe also showed that $T$. aurantiacus is a true thermophile requiring high temperatures for its optimum growth (ranging from $30^{\circ} \mathrm{C}-50^{\circ} \mathrm{C}$ ) and no growth was observed below $30^{\circ} \mathrm{C}$ or lower temperatures. The fruiting body of $T$. aurantiacus was observed to be formed after an incubation period of two days at $40^{\circ} \mathrm{C}$ and this was followed by the pigmentation and ripening process. These fruiting bodies are called "cleistothecia" which are rounded, with a diameter ranging from $0.25 \mathrm{~mm}$ to $1 \mathrm{~mm}$; it exhibits sack-like asci with eight ascospores. These ascospores are elliptical and they are considered to be relatively small in size (5-7 x 4-5 $\mathrm{m}$. When the asci and walls of the ripe cleistothecia disintegrate, these ascospores are released [3, 4].

Thermoascus aurantiacus is a homothallic fungus that is mean it can produce a large amount of uncommonly small sexual ascospores on rich medium within a limited period of time, thus it is essential to distinguish between sexual spores with asexual conidiospores. Thermoascus aurantiacus lacks one of the common features of most Ascomycete fungal species which is dominant asexual mass propagation pattern. However Miehe observed a cystoid blown-up structure, which he found in between thinner sections or terminally. Thus, it could be hypothesized that these cysts are chlamydoconidia or chlamydospores that are considered as rare asexual propagation structures (Figure, 1). Thermoascus aurantiacus strains have been isolated from various habitats, mainly soil and agricultural residues. T. aurantiacus Miehe is IMI 91781, was isolated from alluvial soils in Nottingham, UK. A second strain of T. aurantiacus Miehe, T. aurantiacus Miehe var. levisporus, was isolated from soil sample found in Honduras [10].

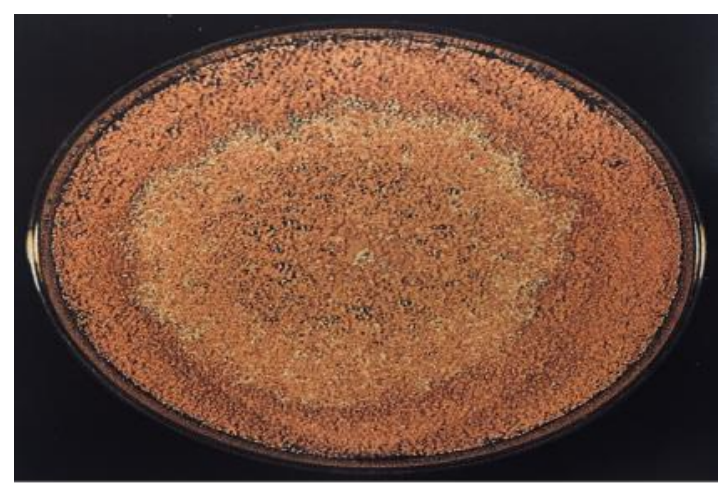

Fig 1: Thermoascus aurantiacus on PDA photo was taken by Dr. Waill Elkhateeb and Dr. Moubasher

\section{Thermoascus aurantiacus factory for enzyme production} Heat-tolerant fungi are potential promising sources of different metabolites as well as heat stable enzymes. Present review has focused on production of thermostable enzymes mainly cellulases and xylanase by Thermoascus aurantiacus. Thermophilic fungi have attracted increased interest for their ability to secrete enzymes that deconstruct biomass at high temperatures. However, development of thermophilic fungi as enzyme producers for biomass deconstruction has not been thoroughly investigated. Comparing the enzymatic activities of thermophilic fungal strains that grow on targeted biomass feedstocks has the potential to identify promising candidates for strain development. Thielavia terrestris and Thermoascus aurantiacus were chosen for characterization based on literature precedents. Several studies have showed that a numerous filamentous fungi are able to synthesize secondary metabolites as well as glycosyl hydrolases with industrial importance [11-15]. Among the thermophilic fungi, the ascomycetous fungus, Thermoascus aurantiacus, is characterized by producing potent enzymes as cellulases, $\beta$-glucosidases, and xylanases. Furthermore, some metabolites that were originated from this fungus extracts are showing biological activity as antioxidant agent. Jain et al., [16] found that Thermoascus aurantiacus produces three cellulases and xylanase with maximum yield after $72 \mathrm{~h}$ of incubation (14.3 IU/g of b-glucosidase, $45.3 \mathrm{IU} / \mathrm{g}$ of CMCase, $8.3 \mathrm{IU} / \mathrm{g}$ of FPase, and 4,000 IU/g of xylanase) [12]. However, any further increase in incubation period resulted in the medium dryness and in turn lower enzyme production. Also, Jain et al., [16] compared the cellulose and xylanases production by different strains of Thermoascus aurantiacus (T. aurantiacus MIEHE and T. aurantiacus RCKK) and other fungal species (Myceliophthora sp. and Pleurotus ostreatus IE8) where the results revealed that $T$. aurantiacus $R C K K$ is able to produce much higher amount of cellulase compared to other fungi. Taking in consideration that the comparison of cellulase and xylanase production with other reports could vary possibly due the differences applied to each assay procedures. 
International Journal of Pharma Research and Health Sciences, 2020; 8 (6): 3237-3241

Another group of enzymes that have been found to be produced by $T$. aurantiacus is alcohol oxidases. In the case of Aspergillus niger and Penicillium chrysogenum, it is known that glucose oxidase couples with catalase. However for $T$. aurantiacus, glucose oxidase was not detected when the fungus was grown on starch to producing catalase. In the case of $T$. aurantiacus, the main enzyme for the production of hydrogen peroxide was alcohol oxidase. Upon the incubation of the fungus on solid medium, the enzyme was produced extracellularly. Although the phenomenon for extracellular production of various enzymes on solid medium is familiar for several fungi including Aspergillus species [17]. The extracellular production of alcohol oxidase has not been reported till Ko et al., [18] reported this phenomenon for the alcohol oxidase.

The studies also reported intracellular alcohol oxidase (AOint) and extracellular alcohol oxidase (AOext) purification (as homogeneous proteins) from both liquid and solid cultural media of $T$. aurantiacus, respectively [20-23]. Contrasting the alcohol oxidases of methanol-utilizing yeasts, the two enzymes: (AOint) and (AOint) from Thermoascus aurantiacus are glycoproteins, and their molecular weights are lower than those of methanol-utilizing yeasts. However, the molecular weights and subunits of (AOint) and (AOext) are markedly different. (AOint) molecular weight as well as that of its subunit are found to be $320 \mathrm{kDa}$ and $75 \mathrm{kDa}$, respectively. (AOint) is supposed to be a homotetrameric enzyme. On the other side, the molecular weight of (AOext) molecular weightis estimated to be $560 \mathrm{kDa}$. (AOext) has two types of subunits with estimated molecular weights $75 \mathrm{kDa}(\alpha)$ and $59 \mathrm{kDa}(\beta)$, respectively. The molecular weights of both subunits as well as the native enzyme itself, is an indicator that (AOext) is a heterooligomeric enzyme. A heterooligomeric alcohol oxidase has been explained in Pichia methanolica yeast [24, 25].

The thermostability region for several enzymesof the methylotrophic yeasts is around $40^{\circ} \mathrm{C}$ and up to $50^{\circ} \mathrm{C}$. Interestingly, the activities of (AOint) and (AOext) are retained at $60^{\circ} \mathrm{C}$ and $55^{\circ} \mathrm{C}$, respectively. Moreover, both (AOint) and (AOext) are stable over a wide range of alkaline $\mathrm{pH}$. These two enzymes exert significant activities towards straight-chain alcohols, and they show the maximum activities towards methanol. It was observed also that (AOext) activity for methanol is almost 7 times that of (AOint).

The basidiomycetes enzymes are able to oxidize aromatic alcohols [20, 21]. Thermoascus aurantiacus inhabits environments especially in locations where decomposing plant materials are abundant, and Thermoascus aurantiacus is frequently isolated from compost at high frequency [13, 22]. These environments are characterized by high production as well as storage of aromatic alcohols and methanol due to the pectin and lignin decomposition. For this reason $T$. aurantiacus showed the optimum growth when cultured on pectin containing medium.

\section{Thermoascus aurantiacus applications}

Thermostable cellulase and xylanase show useful applications in many industries including food, textile, paper, pulp and animal feed, as well as other chemical industries. Since these enzymes can be produced by Thermoascus aurantiacus as it was mentioned in the previous sections, it is likely that Thermoascus aurantiacus could be very useful in the mentioned industries. It was reported that among glycoside hydrolases, cellulases are potent in the cellulose deconstruction to simple hexose sugars, which in turn could be converted into ethanol. Thus Thermoascus aurantiacus finds a great importance in biofuel industries. The ability of $\beta$-glucosidaseto hydrolyse various $\beta$-linked disaccharides, oligosaccharides, alkyl glycosides as well as aryl glycosides gives a promising indication that this fungus could help in enhancing the wine aroma, it could also assist in cellulose hydrolysis process by removing the endproduct inhibition. Xylanases could be very useful in the production of xylooligosaccharides from various agricultural wastes. Moreover, it helps in enhancing the nutritional quality of various animal feeds. Finally it plays an important role in processing paper pulp [26-30].

Alkyl-glycosides and alkyl-polysaccharides show great importance in detergent and other industries. Interestingly, several glycosidases play vital roles in the synthesis of many alkyl and aryl-glycosides of interest as well as substituted polysaccharides via transferase reaction process [31-39]. It was reported that $\beta$-glucosidase and xylanase produced by Thermoascus aurantiacus catalyse the synthesis of alkylglycosides in the presence of methanol, ethanol, propanol and butanol. Additionally, the xylanase produced by Thermoascus aurantiacus catalyse the alkyl- and arylxylooligosaccharides synthesis. These results give promising evidences that Thermoascus aurantiacus enzymes could be very useful in the synthesis of commercial alkyl- and arylglycosides [40-45].

\section{FUTURE PROSPECT}

More studies should be conducted to enhance the production of industrial thermostable enzymes from Thermoascus aurantiacus via the application of different statistical approaches and newly developed molecular biology methods. Also, more effort should be directed towards introducing Thermoascus aurantiacus into new hosts for further studying the deconstruction of plant cell wall.

\section{CONCLUSION}

This review shows the potential of Thermoascus aurantiacus in the production of thermostable enzymes mainly cellulases and xylanase, which are vital to utilize the agricultural residues for the production of biofuel. Moreover, this fungus was reported to be very useful in various industries including 
International Journal of Pharma Research and Health Sciences, 2020; 8 (6): 3237-3241

food, textile, paper, pulp and animal feed, as well as other chemical industries including detergent industry.

\section{REFERENCES}

1. Apinis A. Dactylomyces and Thermoascus. Transactions of the British Mycological Society, 1967; 50:573-82.

2. Béguin P. Aubert J-P. The biological degradation of cellulose. FEMS microbiology reviews 1994; 13:25-58.

3. Berka RM, Grigoriev IV, Otillar R, Salamov A, Grimwood J, Reid I, Ishmael N, John T, Darmond C, Moisan M-C. Comparative genomic analysis of the thermophilic biomass-degrading fungi Myceliophthora thermophila and Thielavia terrestris. Nat Biotech 2011; 29: 922-7.

4. Bertleff W, Neumann P, Baur R, Kiessling D. Aspects of polymer use in detergents. Journal of Surfactants and Detergents 1998; 1:419-24.

5. Bhat M, Bhat S. Cellulose degrading enzymes and their potential industrial applications. Biotechnol Advan 1997: 15: 583-620.

6. Bhat MK, Parry NJ, Kalogiannis S, Beever DE, Owen E. Thermostable Cellulase and Xylanase from Thermoascus aurantiacus and Their Potential Industrial Applications. In Glycosyl Hydrolases for Biomass Conversion vol. 769. Washington D C: American Chemical Society 2000:204-21.

7. Brienzo M, Arantes V, Milagres AM. Enzymology of the thermophilic ascomycetous fungus Thermoascus aurantiacus. Fung Biol Rev 2008; 22:120-30.

8. Bringer S, Sprey S, Sahm H. Purification and properties of alcohol oxidase from Poria contigua. Euro J Biochem. 1979. 101:563-70.

9. Couderc R. Baratti J. Oxidation of methanol by the yeast, Pichia pastoris. Purification and properties of the alcohol oxidase. Agri Biolog chem. 1980; 44:2279-89.

10. Da Silva R, Lago EL, Merheb CW, Macchione MM, Park YK, Gomes E. Production of xylanase and CMCase on solid state fermentation in different residues by Thermoascus aurantiacus. Brazilian J Microbiol 2005; 36: 235-41.

11. Deploey JJ, 1995. Some factors affecting the germination of Thermoascus aurantiacus ascospores. Mycol 87: 362-5.

12. Elkhateeb WA, Zohri AA, Mazen MB, Hashem M, Daba GM. Investigation of diversity of endophytic, phylloplane and phyllosphere mycobiota isolated from different cultivated plants in new reclaimed soil, Upper Egypt with potential biological applications. J Med Pharm Res 2016; 2:23-31.

13. Elkhateeb WA. Some mycological, phytopathological and physiological studies on mycobiota of selected newly reclaimed soils in Assiut Governorate, Egypt (M. Sc. Thesis, Faculty of Science, Assuit University, Egypt. 2005; p 238.
14. Himmel ME, Ruth MF, Wyman CE. 1999. Cellulase for commodity products from cellulosic biomass. Curr Opinion in Biotechnol 10: 358-63.

15. Ichikawa Y, Look GC, Wong C-H. Anal. Biochem. 1992; 202:215-38.

16. Jain KK, Dey TB, Kumar S, Kuhad RC. Production of thermostable hydrolases (cellulases and xylanase) from Thermoascus aurantiacus RCKK: a potential fungus. Bioproc Biosys Engin 2015; 38:787-96.

17. Kalogeris E, Christakopoulos P, Katapodis P, Alexiou A, Vlachou S, Kekos D, Macris BJ. Production and characterization of cellulolytic enzymes from the thermophilic fungus Thermoascus aurantiacus under solid state cultivation of agricultural wastes. Proc Biochem 2003; 38:1099-104.

18. Ko HS, Fujiwara H, Yokoyama Y, Ohno N, Amachi S, Shinoyama $\mathrm{H}$ et al. Inducible production of alcohol oxidase and catalase in a pectin medium by Thermoascus aurantiacus IFO 31693. J Biosci Bioeng 2005; 99:290-2.

19. Kocabas A, Ogel Z,Bakir U. Xylanase and itaconic acid production by Aspergillus terreus NRRL 1960 within a biorefinery concept. Ann of microbiol 2014; 64:75-84.

20. Kuhad RC, Singh A, Eriksson K-EL. Microorganisms and enzymes involved in the degradation of plant fiber cell walls, in Biotechnology in the pulp and paper industry. Springer (Vol 1997; pp. 45-125).

21. Maheshwari R, Bharadwaj G, Bhat M. Thermophilic fungi: their physiology and enzymes. Microbiol Molec Biol Rev 2000; 64:461-88.

22. McClendon SD, Batth T, Petzold CJ, Adams PD, Simmons BA, Singer SW. Thermoascus aurantiacus is a promising source of enzymes for biomass deconstruction under thermophilic conditions. Biotechnol Biofuel 2010; 54: 1-9.

23. Miehe H. 1907. Die selbsterhitzung des heus: Eine biologische studie. G. Fischer; 1907.

24. Milagres AM, Santos E, Piovan T, Roberto IC. Production of xylanase by Thermoascusaurantiacus from sugar cane bagasse in an aerated growth fermentor. Process Biochem 2004; 39:1387-91.

25. Monte JR, Carvalho W, Milagres AM. Use of a mixture of thermophilic enzymes produced by the fungus Thermoascus aurantiacus to enhance the enzymatic hydrolysis of the sugarcane bagasse cellulose. Am J Agric Biol Sci 2010; 5:468-76.

26. Nakagawa $T$, Mizumura $T$, Mukaiyama $H$, Miyaji $T$, Yurimoto H, Kato N, Tomizuka N. Physiological role of the second alcohol oxidase gene MOD2 in the methylotrophic growth of Pichia methanolica. Yeast, 2002; 19:1067-73.

27. Nakagawa $T$, Uchimura $T$, Komagata K. Isozymes of methanol oxidase in a methanol-utilizing yeast, Pichia methanolica IAM 12901. J Fermn Bioeng 1996; 81:498503. 
International Journal of Pharma Research and Health Sciences, 2020; 8 (6): 3237-3241

28. Olofsson K, Wiman M, Lidén G. Controlled feeding of cellulases improves conversion of xylose in simultaneous saccharifications and co-fermentation for bioethanol production. J Biotechnol 2010; 145:168-75.

29. Sannia G, Limongi P, Cocca E, Buonocore F, Nitti G, Giardina P. Purification and characterization of a veratryl alcohol oxidase enzyme from the lignin degrading basidiomycete Pleurotus ostreatus. Biochimica et Biophysica Acta (BBA)General Subjects 1991; 1073:114-9.

30. Santos E, Piovan T, Roberto IC, Milagres AM. Kinetics of the solid state fermentation of sugarcane bagasse by Thermoascus aurantiacus for the production of xylanase. Biotechnol Letters 2003; 25:13-6.

31. Schuerg T, Gabriel R, Baecker N, Baker S, Singer S. Thermoascus aurantiacus is an Intriguing Host for the Industrial Production of Cellulases. Curr Biotechnol 2017; 6:89-97.

32. Schuerg T, Prahl JP, Gabriel R, Harth S, Tachea F, Chen CS, Mirshiaghi M. Xylose induces cellulase production in Thermoascus aurantiacus. Biotechnol for biofuels 2017; 10:1-11.

33. Sharma HS. Economic importance of thermophilous fungi. Appl Microbiol Biotechnol. 1989; 31:1-10.

34. Shinoyama H, Takei k, Andō A, Fujii T, Sasaki M, Doi M, Yasui T. Enzymatic synthesis of useful alkyl $\beta$ glucosides. Agricul biological chem 1991; 55:1679-81.

35. Silva RD, Lago ES, Merheb CW, Macchione MM, Park YK, Gomes E. Production of xylanase and CMCase on solid state fermentation in different residues by Thermoascus aurantiacus miehe. Brazilian J Microbiol 2005; 36:235-41.

36. Sugden C, Bhat M. Cereal straw and pure cellulose as carbon sources for growth and production of plant cellwall degrading enzymes by Sporotrichum thermophile. W J Microbiol Biotechnol 1994; 10:444-51.

37. Suye S-I. Purification and properties of alcohol oxidase from Candida methanosorbosa M-2003. Curr microbiol. 1997; 34: 374-7.

38. Szijártó N, Siika-Aho M, Tenkanen M, Alapuranen M, Vehmaanperä J, Réczey K, Viikari L. Hydrolysis of amorphous and crystalline cellulose by heterologously produced cellulases of Melanocarpus albomyces. J biotechnol 2008; 136:140-7.

39. Tani Y, Vongsuvanlert V. Kumnuanta J. Raw cassava starch-digestive glucoamylase of Aspergillus sp. N-2 isolated from cassava chips. J Ferment Technol 1986; 64:405-10.

40. Upadhyay J, Farmelo M, Goetz S, Melan M. A new variety of a thermophilic mold, Thermoascus aurantiacus var. levisporus. Mycopathol 1984; 87:7180.

41. Viikari L, Alapuranen M, Puranen T, Vehmaanperä J, Siika-aho M. Biofuels: Advances in Biochemical Engineering/Biotechnology. In Thermostable Enzymes in Lignocellulose Hydrolysis Biofuels. vol. 108th edition. Edited by Olsson L. Berlin/Heidelberg: Springer; 2007:121-45.

42. Vonck J, van Bruggen E. Electron microscopy and image analysis of two-dimensional crystals and single molecules of alcohol oxidase from Hansenula polymorpha. Biochimica et Biophysica Acta (BBA)Protein Structure and Molecular Enzymology 1990; 1038:74-9.

43. Waters DM, Murray PG, Ryan LA, Arendt EK, Tuohy MG. Talaromyces emersonii Thermostable Enzyme Systems and Their Applications in Wheat Baking Systems. J Agricul Food Chem 2010; 58:7415-22.

44. Yu J-H, Keller N. Regulation of secondary metabolism in filamentous fungi. Annu Rev Phytopathol 2005; 43:437-58.

45. Zeikus J. In Enzymes in Biomass Conversion, Leatham, GF; Himmel, ME Eds. in ACS Symp. Amercian Chem. Soc., Washington, DC. 1991; (Vol. 460, pp. 36-52).

\section{Conflict of Interest: None Source of Funding: Nil}

